\title{
Performance Improvement by Logistics Collaboration Management Model for Orchid Flower Industry in Thailand
}

\author{
Chattrarat Hotrawaisaya ${ }^{1}$, Watcharavee Chandraprakaikul ${ }^{1}$ \& Nanthi Suthikarnarunai ${ }^{1}$ \\ ${ }^{1}$ University of the Thai Chamber of Commerce, Thailand \\ Correspondence: Chattrarat Hotrawaisaya, University of the Thai Chamber of Commerce, Thailand. E-mail: \\ chattrarat.ho@gmail.com
}

Received: September 29, 2014 Accepted: October 21, 2014 Online Published: October 26, 2014

doi:10.5539/emr.v3n2p52

URL: http://dx.doi.org/10.5539/emr.v3n2p52

\begin{abstract}
This paper aims to present the logistics collaboration management model and performance improvement of orchid flower firms in logistics activities for growers and exporters. The collaboration results improving cost, time and reliability to all parties in the chain. The collaboration management model becomes firms' management tools for competitive advantage among rivals in the industry. The logistics performance indicator model uses to measure the activities between pre and post collaboration. The research contributes the uniqueness logistics collaborative management model which value to orchid industry in Thailand. The orchid flower grower and exporter may use this model as their management tool which aims in competitive advantage.
\end{abstract}

Keywords: logistics, orchid flower, supply chain management, collaboration, performance measurement

\section{Introduction}

\subsection{Orchid Industry}

Orchid flower is one of the most important products in Thailand. The Office of Agricultural Economics found that in 2005, the orchid flowers export value was 3,000 million Thai Baht from the approximately 8,198 acres which produced 20,944 kilograms (Arganistapechart, 2005). Two types of orchid (cut flower and plant) could be cultivated as illustrated in Table 1. The Dendrobium orchid is the most favorite in many markets, including Thailand because it is colorful and long life. Thailand was the number one in term of the producer and exporter of Dendrobium orchid (Dhamniyam, 2013).

Table 1. Type of orchid (Everythings Orchid, 2013)

\begin{tabular}{lll}
\hline & \multicolumn{2}{c}{ Value Share (\%) } \\
\cline { 2 - 3 } Orchid Genera & Cut Flower & Orchid Plant \\
\hline Arachnis & - & 0.01 \\
Aranda & - & 0.48 \\
Aranthers & - & 0.52 \\
Ascocenda & 1.20 & 0.01 \\
Catleya & 2.70 & - \\
Cymbidium & 0.30 & - \\
Dendrobium & 51.40 & 94.72 \\
Epidendrum & 0.60 & - \\
Mokara & 3.70 & 3.69 \\
Oncidium & 3.10 & 0.44 \\
Paphiopedilum & 0.20 & - \\
Phalaenopsis & 25.50 & - \\
\hline
\end{tabular}




\begin{tabular}{lll}
\hline Rhynchostylis & 0.30 & - \\
Spathoglottis & 0.30 & - \\
Vanda & 8.90 & 0.13 \\
Others & 1.80 & - \\
\hline
\end{tabular}

\subsection{Problem}

As the orchid flower revenue gradually decreased from year 2007 to 2012 at annual average of $3.59 \%$, which has produced average lost 84.22 million Thai Baht per year. The table 2 and the figure 1 illustrated the number of orchid flower export if decreased gradually.

Table 2. Reduction of orchid flower export (2007-2012) (Thai Custom Department, 2013)

\begin{tabular}{lll}
\hline Year & Lost (THB) & Reduce (\%) \\
\hline 2007 & N/A & N/A \\
2008 & $-104,727,833.00$ & $-4.16 \%$ \\
2009 & $-44,644,412.00$ & $-1.85 \%$ \\
2010 & $-61,278,037.00$ & $-2.59 \%$ \\
2011 & $-84,962,040.00$ & $-3.69 \%$ \\
2012 & $-125,498,456.00$ & $-5.65 \%$ \\
\hline Average & $-84,222,155.60$ & $-3.59 \%$ \\
\hline
\end{tabular}

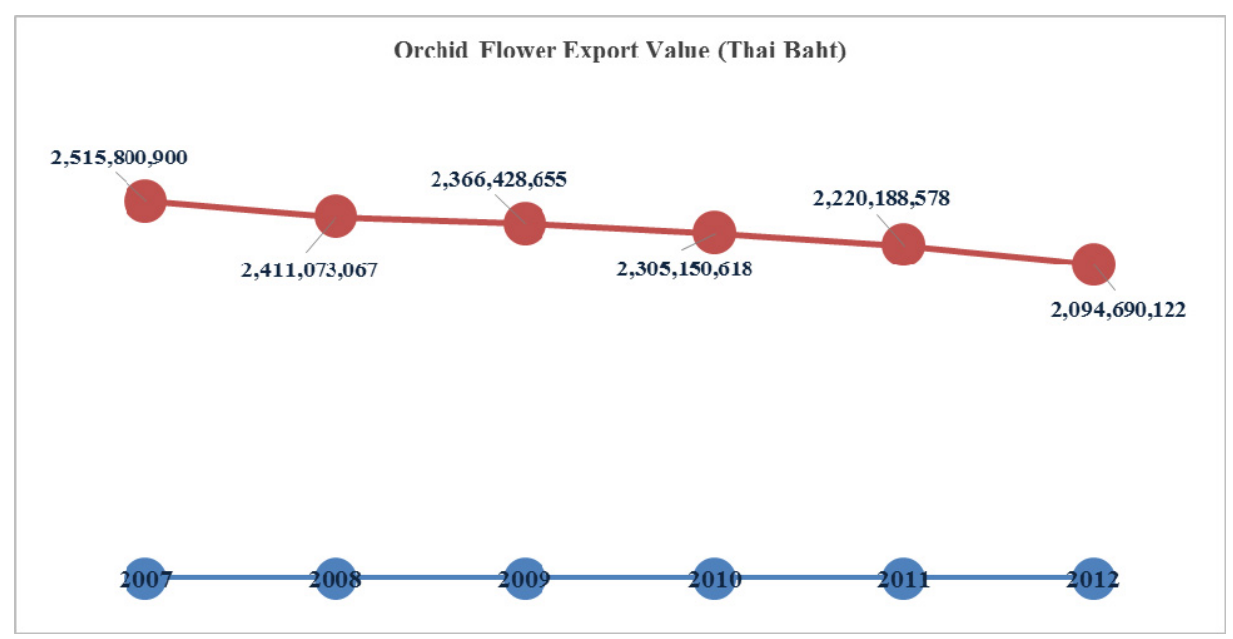

Figure 1. Orchid flower export value (Thai Baht) 2007-2012

Moreover, the quantity of orchid flower per kilogram also reduced during 2007 to 2012. It showed that both quantity and revenue were continuously reducing. By forecasting technique, the export value in 2020 will be 1,497 million Thai Baht which equal to 18,506,510 kilograms of orchid. This phenomenon has direct resulted in Thai orchid flower industry, both growers and exporters. They encounter the fiercely competitive world market and may be eventually business (Nuchanapai, 2012). 


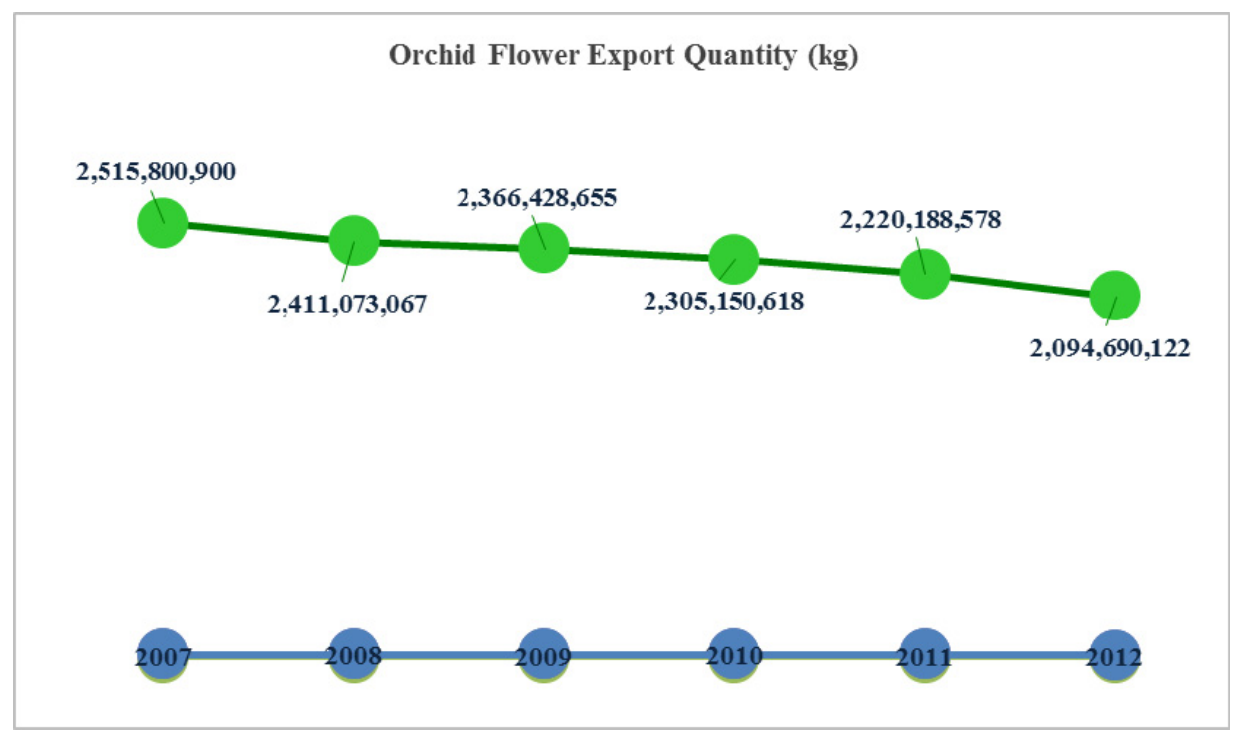

Figure 2. Orchid flower export quantity (kg) 2007-2012

There are several collaborative research studies in orchid by researchers, government agencies, academia and stakeholders are related to orchid supply chains. The researchers found the three main problems that are (1) a high transportation cost; 2) low delivery and fluctuated orchid quantity distribution; and 3) a high damaging cost. The department of agriculture provides new technology, fund, and knowhow to develop new species and improving production quality. The member in orchid supply chain must participate and develop the strategies in order to improve Thai orchid industry together, especially logistics cost in the supply chain, which is proportionally higher than $60 \%$ of the sale price (Mahidol, 2013). Logistics activities are located in all parts of the orchids supply chain. Besides, logistics cost reduction is a key to increase international market share.

\subsection{Literature Review}

\subsubsection{Supply Chain Collaboration}

Supply chain collaboration is a new strategy that is used in many businesses and has been success for many years. It can be seen that this is a new trend to integrate supplier, manufacturer and customers accomplish the same goal or win-win situation (Ramanathan et al., 2011) and (Simatupang \& Sridharan, 2005).

The end customer will have their own requirement with this strategy, producers will receive demand and then this should be managed in the supply chain. As previous research undertaken Grocery Manufacturer Association supported the importance of supply chain collaboration has delivered real value for suppliers, vendor, manufacturer and related participants as the CCM survey found that the only two in ten of their collaboration significant results. If companies cannot make collaboration yield in supply chain, they will encounter risk and barriers in both organization and trading partners (Benavides et al., 2012). The Cranfield School of Management investigated the drivers of success and failure in 54 long-term relationships. This research demonstrated that often a cycle of failure within the relationship could develop, creating a situation where neither party would gain advantage and where the supply chain was therefore improve service performance, profits, relationship has effective to customers and suppliers within the firm (Humphries \& Wilding, 2004).

Fawcett (2012) defined supply chain collaboration as vital, dynamic capability, able to derive different performance. Collaborative initiatives can involve suppliers and customers-vertical collaboration-or competitors and other organizations in a similar supply chain echelon (Barratt, 2004), and the continuum of collaborative relationships spans from arm's length to vertical integration (Lambert et al., 1996). However, highly collaborative initiatives are costly, resource intensive and their outcomes are often unpredictable. Further, barriers to collaboration have been identified in the existing literature. They include the unwillingness to share information and lack of trust in trading partner (Barratt, 2004), unclear and uncomfortable roles, perception of lack of mutuality and symmetry (Palmer et al., 2012), the mistrust about the fairness of benefit, costs and risk sharing (Rossi, 2012). All of these barriers depict a high level of complexity.

One of the most important areas embraced by the supply chain management philosophy is logistics. Logisticians 
are, by nature, occupied with cross-functional activity and Supply Chain Management and therefore had enormous importance in logistics research the last two decades. Within the field of logistics, we know about best practice companies that have applied collaboration based on the supply chain management philosophy and have achieved extraordinary good results. Logistics collaboration is a new technique in supply chain collaboration which can reduce costs, increase profits and get high customer satisfaction (Hwang \& Seruga, 2011). The table 3 is summarized research paper in term of 9 logistics activities in supply chain collaboration. The table 3 concludes 9 logistics activities. They are customer service (1), order processing (2), demand forecasting and planning (3), inventory management (4), transportation (5), warehousing (6), reverse logistics (7), material handling and packaging (8), and logistics communication (9).It found that they are not using all nine logistics activities in agriculture.

Table 3. Summary of research papers in the area of supply chain collaboration in orchid industry

\begin{tabular}{|c|c|c|c|c|c|c|c|c|c|}
\hline No & Researcher & 1 & 2 & 3 & 4 & 5 & 6 & 7 & 8 \\
\hline 1 & Akintoye A (2000) & & / & / & / & I & / & & 1 \\
\hline 2 & Sheffi (2002) & & & / & / & & & & \\
\hline 3 & Karuranga, Frayet, D’Amour (2002) & & / & / & / & / & / & & / \\
\hline 4 & Fu and Piplani (2004) & & & & / & & & & \\
\hline 5 & Kholi and Jensen(2010) & & & / & & & & & \\
\hline 6 & Aslan and Ahmet (2013) & & & / & & & & & \\
\hline 7 & Salema, Póvoa, \& Novais (2008) & / & / & & & & & & / \\
\hline 8 & Fathen, Muhammad, \& Egide (2012) & & & & & & & & \\
\hline 9 & Caridi, Cigolini and Marco (2005) & & & / & & & & & \\
\hline 10 & Simatupang and Sridharan (2005) & & & / & / & & & & \\
\hline 11 & Taylor (2006) & & & / & & & & & \\
\hline 12 & Danese(2007) & & & / & & & & & \\
\hline 13 & Sandberg (2007) & & & / & & & & & \\
\hline 14 & Power (2008) & & / & / & & & & & \\
\hline 15 & Mugarura (2008) & & & / & & & & & \\
\hline 16 & Mugarura (2008) & & & / & & & & & \\
\hline 17 & Betts and Tadisina (2009) & & / & l & / & / & / & & \\
\hline 18 & Du, Leung, Zhang and Lai (2009) & & & / & & / & & & \\
\hline 19 & Chen, Chen and Lai (2010) & & & l & & / & & & \\
\hline 20 & Mathuramaytha (2011) & & / & / & / & & & & \\
\hline 21 & Ramanathan and Muyldermans (2012) & & & / & & & & & \\
\hline 22 & Taijidan, Budi, Muslich, \& Wahib (2013) & & l & / & / & & & & \\
\hline 23 & Eksoz, Mansouri, \& Bourlakis (2014) & 1 & 1 & & & & & & \\
\hline
\end{tabular}

\subsection{Discussion}

The review of literature above discusses the definitions and theories, as well as the previous and recent works of collaboration in supply chain that impact supply chain performance and supply chain cost. Previous and current researches on the collaboration model have become very important in variety of contexts. There are few reports investigating the model that leads to determining supply chain performance, but determining supply chain cost using the above model has not been yet investigated. It is explicit that a correlation between supply chain performance and supply chain cost should be thoroughly identified. It is assumed that this literature review is an indication of establishing the theory, conceptual model, as well as defining the hypothesis and research methodology of collaboration model. The previous research focused on new orchid species development and 
export business, but never discussed about logistics activities and supply chain collaboration. Therefore, this research study will try to fill the gap of previous research by finding the logistics collaboration in orchid supply chain and performance evaluation.

\section{Methodology}

The methodology of this research is separated into two parts. Part one is model formation and Part two is a model adjustment in the orchid industry. Model formation includes an in-depth interview and questionnaire. The purposive sample of this research is the fifty orchid companies in Bangkok, Thailand (Bangkok Business Directory, 2012). They have been registered with the Bangkok Metropolitan Administration. This research employed the procedure by Lundahl and Skärvad (1999). The questionnaire and in-depth interview are described in figure 3.

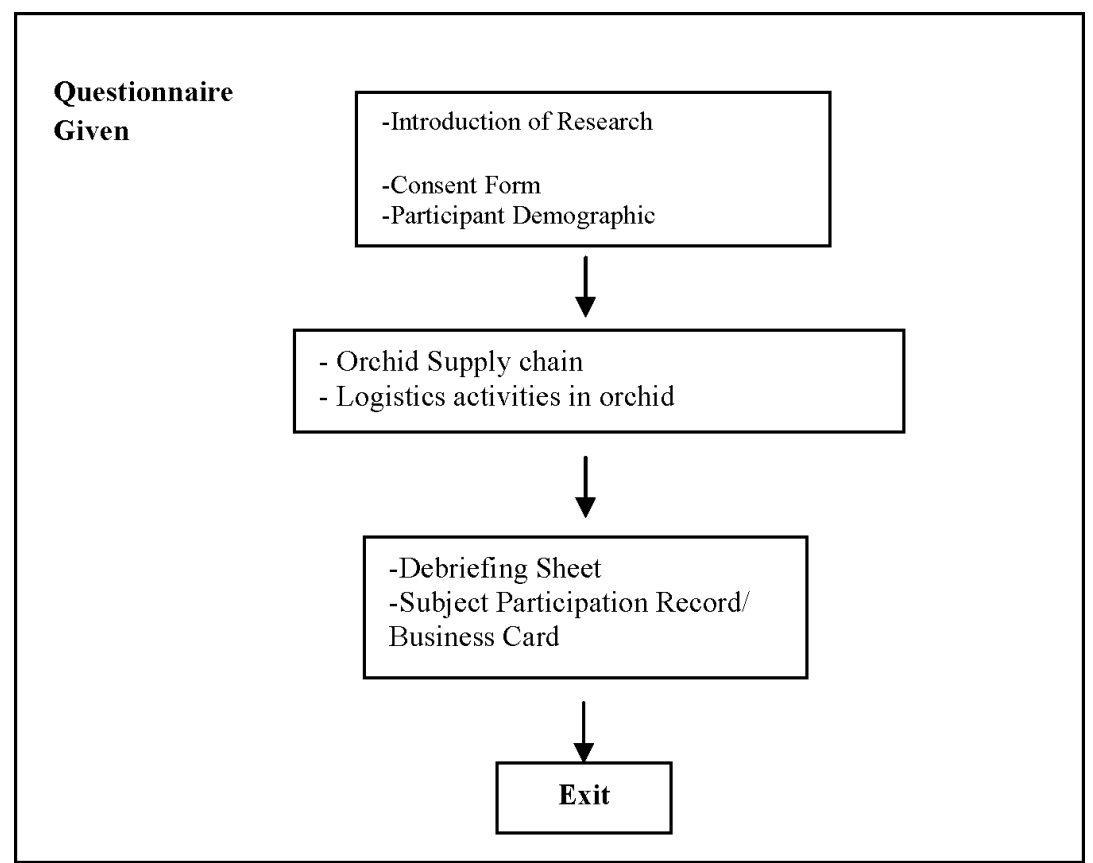

Figure 3. Schematic diagram of data collection procedure

The discussion in the in-depth interview is related consistency, applicability, time, and understanding of orchid flower supply chain, logistics activities and collaboration among stakeholders (Lim, 2007). The researcher uses this information to create an orchid supply chain and Logistics collaboration model for orchid flower industry. Model adjustment consists of a pilot test with pre and post implementation. The researcher uses a volunteer sampling method. They are the group of the research's population. The sampling consists of ten growers and one exporter. Data collection is set up for 120 days with logistics performance indicator. They are shown in Table 4 . The data are evaluated by using T-test statistics analyze.

\section{Result of Model Formation}

\subsection{Orchid Supply Chain}

From questionnaire and in-depth interview, it is found that stakeholders that support the industries, are growers, exporter, wholesaler, retailer and customer (Figure 4). Supported industries are related to orchid tissue, insecticide, fertilizer, packaging, and orchid tools. There are located near orchid farms. Growers will not order in advance or overstock as these are used one in every two to three months. Moreover, the price is fluctuate and usually high. An orchid is being planted and cultivated in the grower's warehouse. Different species have different cultivation time. The orchid life cycle is two to ten years. After cutting, grower will select orchid size, number of orchids, length of orchid bouquet and color. These orchids pass quality control, and then they are sent to the exporter. If they fail, they will be sent to local wholesalers. Exporters will double check the orchid quality, pest control and re-packaging before they are transport to the airport. Then all orchid bouquets and plants will be export to international retailers and end customers. Along orchid supply chain has logistics activities (Kaipia et al., 2013). 


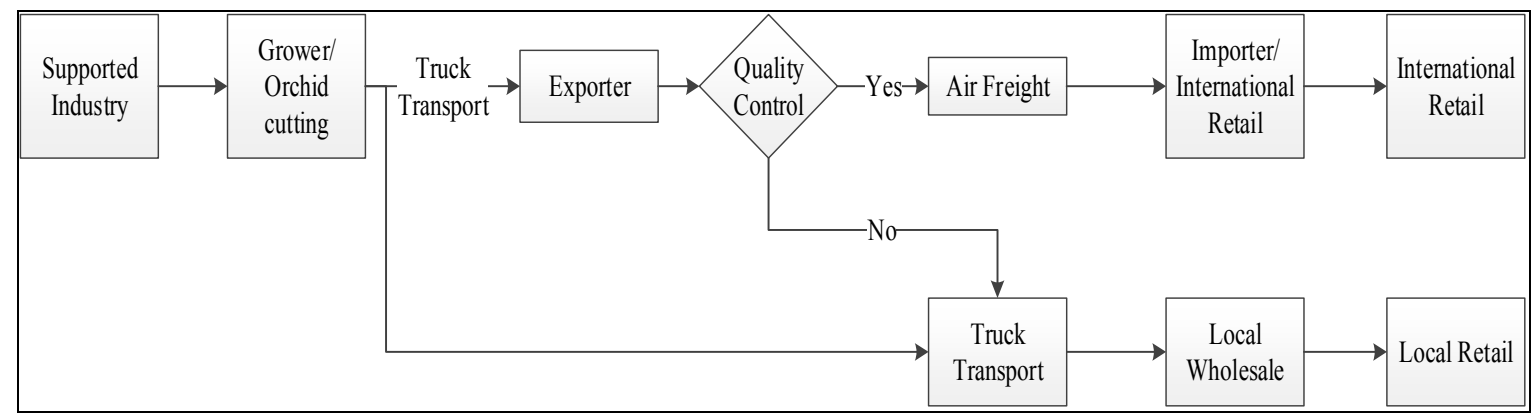

Figure 4. Orchid supply chain

\subsection{Logistics Collaboration Flow Diagram}

However, collaboration, there are demand forecasting, order processing, inventory management, warehouse and storage, order processing and transportation. Logistics Collaboration in Orchid Supply Chain is related to third parties. There are grower, exporter and international/local retailer. It is shown in Figure 5: The process, material and Information flow in Logistics Collaboration. The steps insist on demand forecasting, inventory management, warehouse and storage, order processing and transportation management (Stefansson, 2006).

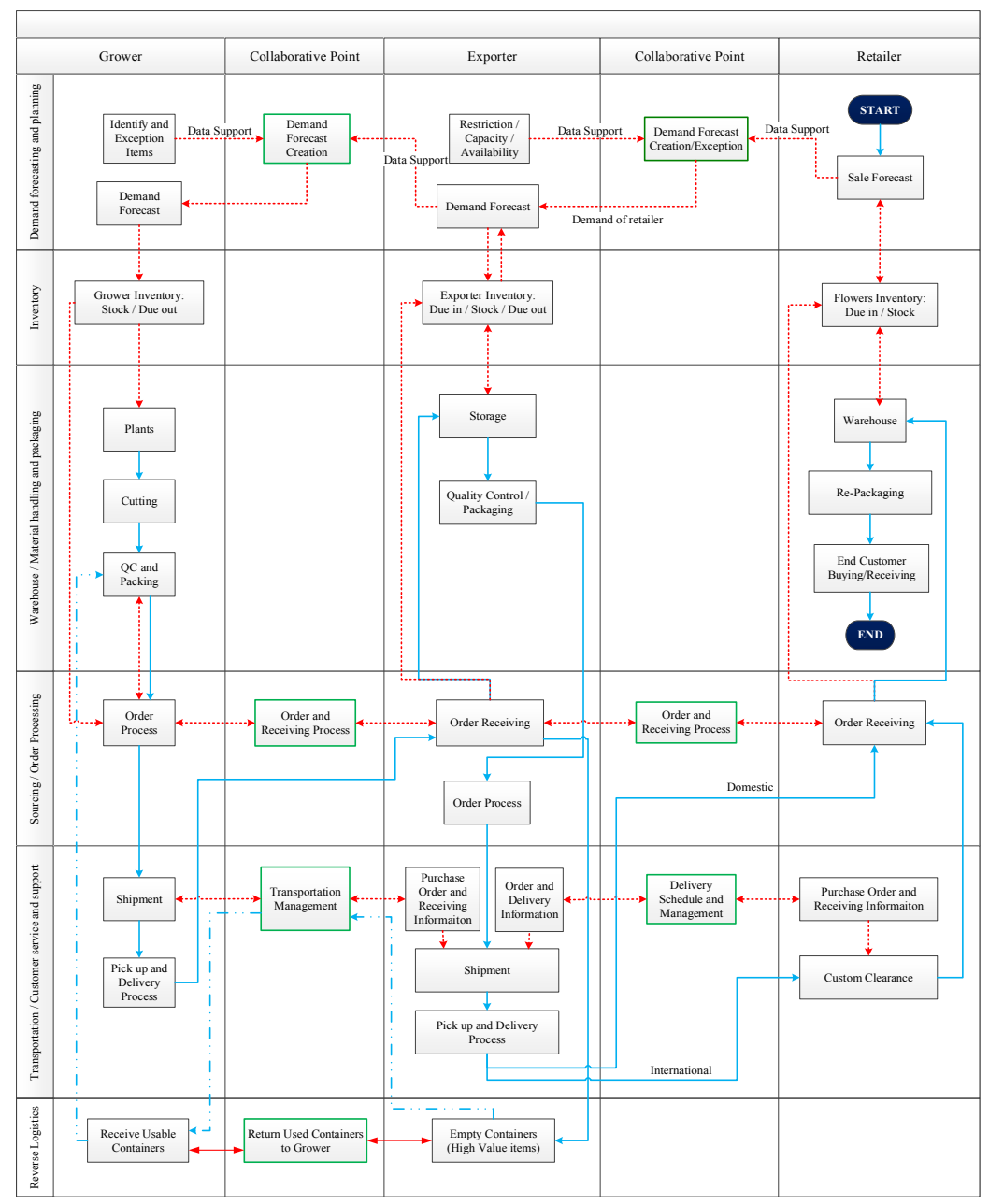

Figure 5. Logistics collaboration management flow diagram 


\subsubsection{Demand Forecasting and Planning}

In demand forecasting process has 6 steps. There is Item identification, Item exception, Demand forecasting set up, Demand forecasting development, Result publishing and Demand forecasting assessment. The details are as follow: (1) Identify Item: The party identifies orchid types of each party that are in hand or customer requirement They support this information to collaborative point for finding out the best forecasting method; (2) Exception Item: As orchid types are different forecasting and quitting times, orchid demand and supply should be matched at this point; (3) Set up demand forecasting: Both parties should decide forecasting method that is suitable to orchid type. There are trendy, seasonal, cycle and random; (4) Develop demand forecasting: Selected forecasting method should be tested and developed for all orchid types that they order or plant; (5) Publish the results: Parties collect data before and after use forecasting method. This key in computer that shares information between parties; (6) Access demand forecasting accuracy: Comparing data is used in this step. MAD, MSE and MAPE are evaluated forecasting accuracy (Poler et al., 2008)

\subsubsection{Inventory Management}

In orchid farms, the inventory starts since planting orchid trees, then they keep growing in the same place which we call "Plant". Meanwhile, it is the same place of warehouse until the flower is cutting and delivering to customers (Nasiri et al., 2010)

\subsubsection{Warehouse, Material Handling and Packaging}

The warehouse and storage diagram can separate five steps. There are information receiving, production process, order picking, quality control and packing. Generally, this process cannot collaborate each other, but information from another process should also be generated in this process. Moreover, warehouse and storage is unique each party. The researcher has to disrupt each party. There are grower, exporter and retailer (Bloss, 2014).

1) Information Receiving/Product Receiving

A grower receives demand forecasting for plants that are one-two years before cutting. Information support grower to plan the growth of orchid tissues.

\section{2) Production Process/Storage}

Orchid tissue is planted, maintain, and fertilize. Orchid bouquet and plant are stored in the warehouse / form.

3) Quality Control

The grower must select orchid size, color, the length of orchid bouquet, number of orchid/bouquet and pest control. Unfortunately, quality control is not passed, orchids become damaged product or sale in the local market.

\section{4) Packaging}

After cutting, the orchid bouquet is packed in a plastic box and cover with a white flat sheet. This plastic box has limited for overlap as damage may happen in this situation.

\subsubsection{Sourcing and Order Processing}

Sourcing is the activity of exporter issued the purchase order to growers by indicating the number of flowers, color, lead time and species. One copied of purchasing order must be sent to receiving for products following and controlling.

After receiving purchase order from the exporter, the grower must review the number/species of flowers in their plants. Then they must do delivery schedules to fulfill purchase orders. Beside the grower should inform exporter 3 days before delivery. The exporter has to picking, packing, staging and load configuration. Moreover, they must booking the flights to end customer destination. Therefore, default to fulfill customer receiving schedule results in damaging of orchid flowers which produce loosing (Sawik, 2013).

\subsubsection{Transportation and Customer Service and Support}

Transportation management is the last process of Logistics collaboration. It insists of order receiving, transportation design route/delivery schedule and pickup and delivery. In orchid supply chain has two modes of transportation; air and road modes. However, an orchid flower is a perishable product, times and speed is limited (Lin, 2008).

\section{1) Order Receiving}

All parties receive orders to delivery. Information is for order processing. 


\section{2) Transportation Design}

After order receiving, each party sends information to collaborative point that is about the number of orders, number of orchid bouquet from orchid farms, and schedule of vehicles/3PLs. Therefore, the exporter/local wholesale designs route to pick up.

\section{3) Delivery Schedule}

The exporter/local wholesale set up pickup and delivery schedule and communicates with 3PLs, growers and retailer with time schedule. Normally, it is two times per day as it relates to airplane schedule.

\section{4) Pickup and Deliver}

The last step is pickup and delivery products from grower to retailer. Documentation is happening in this process for the example, airway bill, Phytosanitary Certificate, and notice arrival. Especially, the international market has custom clearance process and taxation.

The after sale service is a product quality guarantee. Once, the exporter receives an orchid flower from growers. Some flower may lower quality (size, color and number of flowers per bucket) than previous mutual agreement. The grower will not charge the price on this low quality item and allow the exporter to keep that product to other purpose.

\subsubsection{Reverse Logistics}

As this product is perishable, it is rarely possible that orchid flowers are reversed in the supply chain because of low life cycle time. In case of a container of orchid flowers is used in this model. As the container can rotate between growers and an exporter so that the cost of production can be decreased in this logistics activity (Kroon \& Vrijens, 1995).

\subsubsection{Information Management}

Data is the most important part of the collaboration. They are orchid species, number of products, routes, demand season, and etc. This logistics activity is the most important of collaboration model. As each party has to collect all internal data and share needed data to partner for gaining a higher collaborative performance (Kimiloglu et al., 2012).

\subsection{Logistics Collaboration Management Model}

As shown in Figure 6, the partnership operation among parties in the supply chain has to share its information each other which is most difficult. They must gain the benefit in order to share information with the others. 


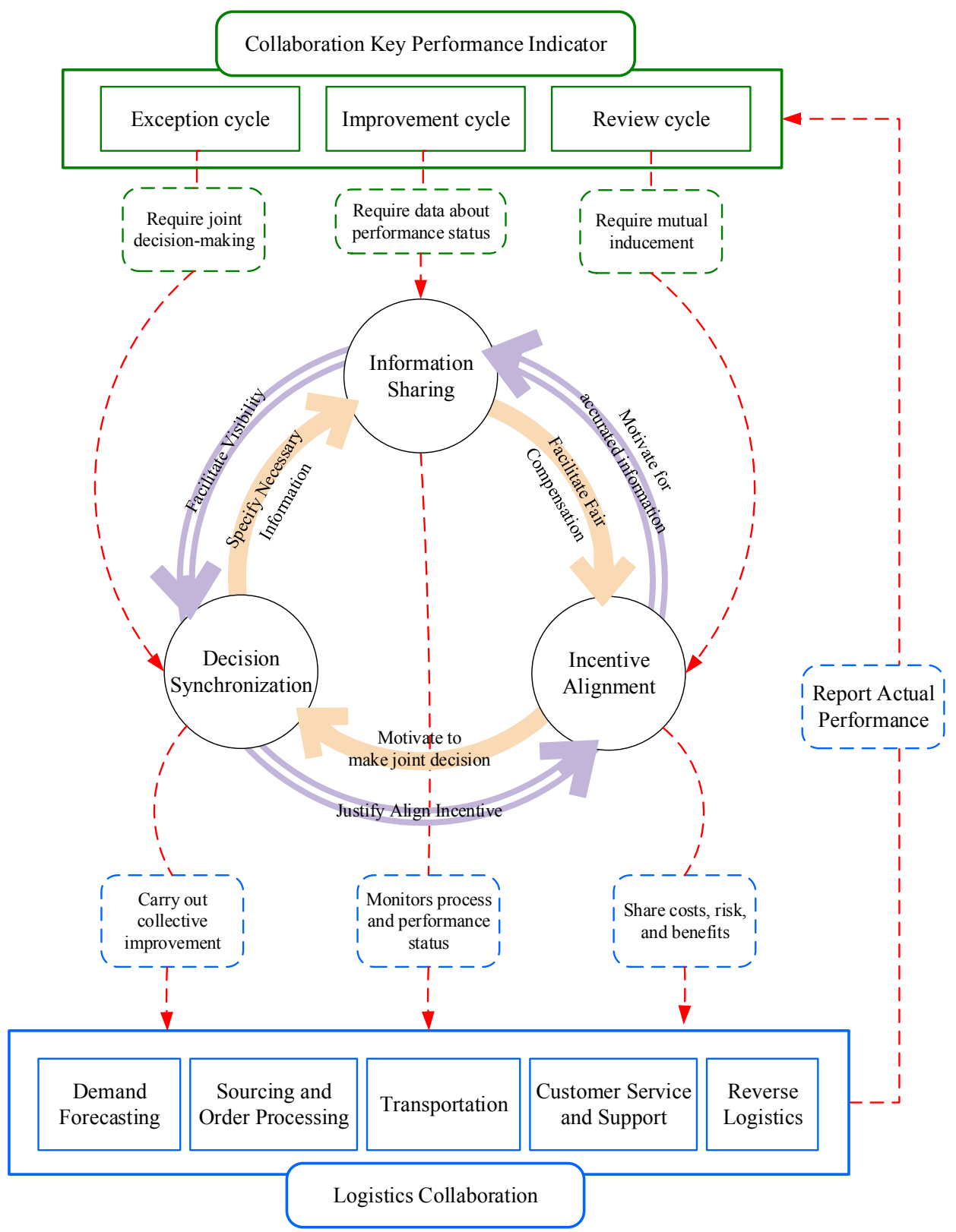

Figure 6. Logistics collaboration management model

\subsubsection{Information Sharing}

The key of collaboration in supply chain is information sharing. The information sharing expects to gain and circulate the essential information to enable decision maker and manage operations. The effective information sharing makes a combined operating by the members of the supply chain. Beside, Information sharing has enabled the members to create a better performance (Peel \& Rowley, 2010).

\subsubsection{Decision Synchronization}

A decision-synchronization is joint decision making at the planning and operation of chain members. The chain member firms use a joint decision as a guide in their logistics processes. The planning circumstance combines decisions about long term planning and measures such as selecting target markets, product classification, customer service level, and forecasting. The operational circumstance combines order generation and delivery process. It can be in the forms of shipping schedule and replenishment of the products to the stores. A decision synchronization challenges the members to participate in all decisions for a common target of serving end customers. It improves supply chain alignment and reduces the gap between delivery requirements and actual 
delivery of parts, which enhance an ordering fulfillment performance. The end customers are satisfied the products suit to their expectation at the right time and reasonable price (Eyaa, et al., 2010).

\subsubsection{Incentive Alignment}

An incentive alignment is the level of which supply chain members share cost, risks, and benefits. Each party must share the cost of administration and technology, which are necessary for collaborative activities. The benefit sharing is an incentive to members' effort in participating in collaborative activities. The benefits of collaboration are commercial gain and performance improvement (Piplani \& Fu, 2005).

\subsection{Key Performance Indicator of logistics collaboration in Orchid Flower Supply Chain}

There are three performance indicator categories: cost, time, and reliability. They measure nine logistic activities: Customer Service and Support, Sourcing, Logistics-Communication and Order Processing, Transportation, Facilities Site Selection/Warehouse and Storage, Demand Forecasting/Planning, Inventory Management, Material Handling/Packaging, and Reverse Logistics as shown in Table 4 (Frazelle, 2002).

Table 4. The logistics performance indicators

\begin{tabular}{|c|c|c|c|c|}
\hline \multirow{2}{*}{ Item } & \multirow{2}{*}{ Logistics Activity } & \multicolumn{3}{|c|}{ Logistics Performance Indicator } \\
\hline & & Cost & Time & Reliability \\
\hline 1 & $\begin{array}{l}\text { Customer service and } \\
\text { support }\end{array}$ & $\begin{array}{c}\text { Ratio of Customer } \\
\text { Service Cost per Sale }\end{array}$ & $\begin{array}{c}\text { Average Order Cycle } \\
\text { Time }\end{array}$ & $\begin{array}{c}\text { Delivery in Full and On } \\
\text { Time Rate }\end{array}$ \\
\hline 2 & Sourcing & $\begin{array}{l}\text { Ratio of Procurement } \\
\text { Cost per Sale }\end{array}$ & $\begin{array}{l}\text { Average Procurement } \\
\text { Cycle Time }\end{array}$ & $\begin{array}{l}\text { Supplier in Full and On } \\
\text { time Rate }\end{array}$ \\
\hline 3 & $\begin{array}{l}\text { Logistics Communication } \\
\text { and Order Processing }\end{array}$ & $\begin{array}{c}\text { Ratio of Logistics } \\
\text { Communication Cost } \\
\text { per Sale }\end{array}$ & $\begin{array}{c}\text { Average Order } \\
\text { Processing Cycle Time }\end{array}$ & Order Accuracy Rate \\
\hline 4 & Transportation & $\begin{array}{c}\text { Ratio of Transportation } \\
\text { Cost per Sale }\end{array}$ & $\begin{array}{c}\text { Average Delivery } \\
\text { Cycle Time }\end{array}$ & $\begin{array}{c}\text { Delivery in Full and On } \\
\text { Time Rate }\end{array}$ \\
\hline 5 & $\begin{array}{l}\text { Facilities Site Selection, } \\
\text { Warehousing and Storage }\end{array}$ & $\begin{array}{l}\text { Ratio of Warehouse } \\
\text { Cost per Sale }\end{array}$ & $\begin{array}{l}\text { Average Inventory } \\
\text { Cycle Time }\end{array}$ & Inventory Accuracy \\
\hline 6 & $\begin{array}{l}\text { Demand Forecasting and } \\
\text { Planning }\end{array}$ & $\begin{array}{l}\text { Ratio of Forecasting } \\
\text { Cost per Sale }\end{array}$ & $\begin{array}{l}\text { Average Forecast } \\
\text { period }\end{array}$ & Forecast Accuracy Rate \\
\hline 7 & Inventory Management & $\begin{array}{l}\text { Ratio of Inventory } \\
\text { Holding Cost per Sale }\end{array}$ & Average Inventory Day & $\begin{array}{c}\text { Inventory Out of Stock } \\
\text { Rate }\end{array}$ \\
\hline 8 & $\begin{array}{l}\text { Material Handling and } \\
\text { Packaging }\end{array}$ & $\begin{array}{c}\text { Ratio of Value Damage } \\
\text { per Sale } \\
\text { Ratio of Return }\end{array}$ & $\begin{array}{c}\text { Average Material } \\
\text { Handling and } \\
\text { Packaging Cycle Time }\end{array}$ & Damage Rate \\
\hline 9 & Reverse Logistics & $\begin{array}{c}\text { Container Value per } \\
\text { Sale }\end{array}$ & $\begin{array}{l}\text { Average Cycle Time for } \\
\text { Container Return }\end{array}$ & $\begin{array}{l}\text { Rate of Return } \\
\text { Container }\end{array}$ \\
\hline
\end{tabular}

\subsection{Data Analysis}

From model adjustment with ten growers and one exporter, can summarized in table 4, 5, and 6 . They are cost, time and reliability. The pre and post performances are tested by t-test for independent sample. If the result of $\mathrm{t}$-test shows the non - difference between pre and post performances, that performance indicator will be dropped off. 
Table 5. Result of cost logistics performance

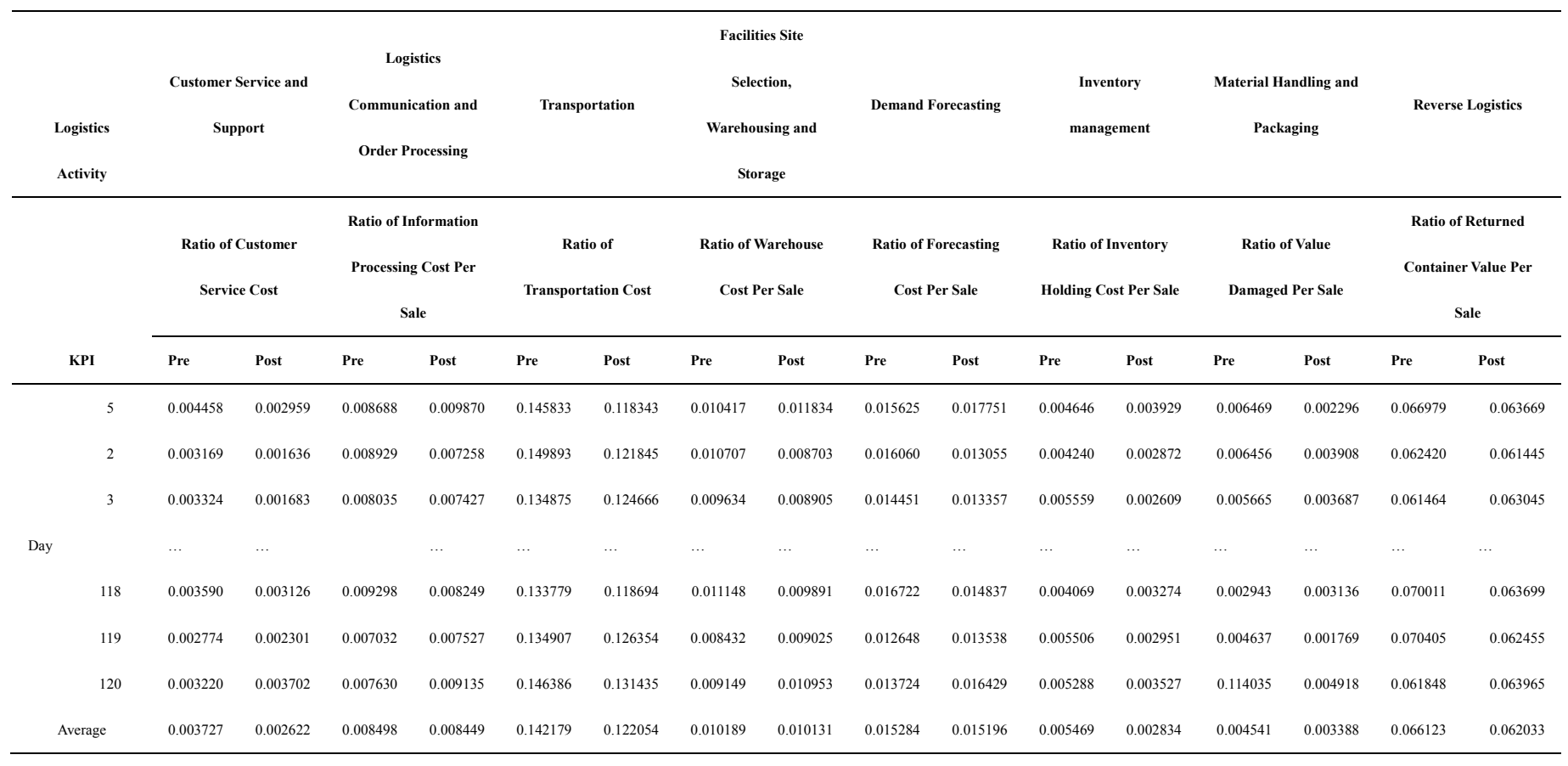

The table 5 shows the result of each logistics performance in term of cost per revenue for 120 days. Cost performance measurement shows pre and post implementation result from one grower of the selected growers. From average cost of nine logistics activities is found that most of them are decreasing. There are customer service, sourcing, transportation, inventory management, material handling and packaging, and reverse logistics at $0.19 \%, 0.15 \%, 1.56 \%, 0.24 \%, 0.15 \%$ and $0.02 \%$. However, logistics communication, facilities, site selection and warehousing storage, and demand forecasting and planning rarely increase by $0.01 \%$.

Table 6. Result of time logistics performance

\begin{tabular}{|c|c|c|c|c|c|c|c|c|c|c|c|c|c|c|c|c|}
\hline \multirow[t]{3}{*}{$\begin{array}{l}\text { Logistics } \\
\text { Activity }\end{array}$} & \multicolumn{2}{|c|}{$\begin{array}{c}\text { Customer } \\
\text { Service and } \\
\text { Support }\end{array}$} & \multicolumn{2}{|c|}{$\begin{array}{l}\text { Communication } \\
\text { and Order } \\
\text { Processing }\end{array}$} & \multicolumn{2}{|c|}{ Transportation } & \multicolumn{2}{|c|}{$\begin{array}{c}\text { Selection, } \\
\text { Warehousing and }\end{array}$} & \multicolumn{2}{|c|}{ Demand } & $\begin{array}{r}\text { Inv } \\
\text { mana }\end{array}$ & tory & \multicolumn{2}{|c|}{$\begin{array}{c}\text { Material } \\
\text { Handling and }\end{array}$} & \multicolumn{2}{|c|}{$\begin{array}{l}\text { Reverse } \\
\text { Logistics }\end{array}$} \\
\hline & Orde & Cycle & Order $P$ & $\begin{array}{l}\text { cessing } \\
\text { Time }\end{array}$ & Delive & Cycle & Invent & Cycle & & & Inv & tory & $\begin{array}{r}\text { Ma } \\
\text { Hand } \\
\text { Pac } \\
T\end{array}$ & $\begin{array}{l}\text { rial } \\
\text { g and } \\
\text { ging } \\
\text { e }\end{array}$ & $\begin{array}{r}\text { Cycle } \\
\text { Con } \\
\operatorname{Re}\end{array}$ & $\begin{array}{l}\text { me for } \\
\text { iner } \\
\text { rn }\end{array}$ \\
\hline & Pre & Post & Pre & Post & Pre & Post & Pre & Post & Pre & Post & Pre & Post & Pre & Post & Pre & Post \\
\hline 1 & 17 & 12 & 5 & 4 & 3 & 3 & 72 & 69 & 60 & 37 & 7 & 3 & 4 & 4 & 19 & 9 \\
\hline 2 & 16 & 10 & 3 & 5 & 1 & 3 & 66 & 69 & 60 & 39 & 7 & 7 & 2 & 2 & 15 & 10 \\
\hline 3 & 17 & 11 & 3 & 4 & 1 & 2 & 75 & 74 & 60 & 39 & 9 & 4 & 3 & 3 & 16 & 9 \\
\hline Day & $\cdots$ & $\cdots$ & $\cdots$ & $\cdots$ & $\cdots$ & $\ldots$ & $\cdots$ & $\ldots$ & $\ldots$ & $\cdots$ & $\cdots$ & $\cdots$ & $\cdots$ & $\cdots$ & $\cdots$ & $\cdots$ \\
\hline 118 & 18 & 11 & 5 & 3 & 3 & 2 & 72 & 75 & 60 & 35 & 5 & 5 & 2 & 2 & 15 & 12 \\
\hline 119 & 17 & 12 & 4 & 3 & 2 & 3 & 68 & 65 & 60 & 40 & 8 & 6 & 3 & 3 & 12 & 8 \\
\hline 120 & 20 & 14 & 4 & 5 & 2 & 2 & 74 & 74 & 60 & 30 & 7 & 3 & 2 & 3 & 19 & 9 \\
\hline Average & 17.94 & 11.90 & 3.97 & 4.14 & 1.95 & 1.92 & 69.92 & 70.19 & 60.00 & 35.32 & 7.42 & 5.03 & 3.06 & 3.16 & 15.08 & 8.70 \\
\hline
\end{tabular}


The table 6 illustrates time performance of logistics activities of one grower with 120 days. They are order cycle time, procurement cycle time, order processing cycle time, delivery cycle time, inventory cycle time, the forecast period, inventory day, material handling and packaging time and cycle time for container return. The average of time of nine logistics activities are all reduced from $0.09 \%$ to $22.42 \%$.

Table 7. Result of reliability logistics performance

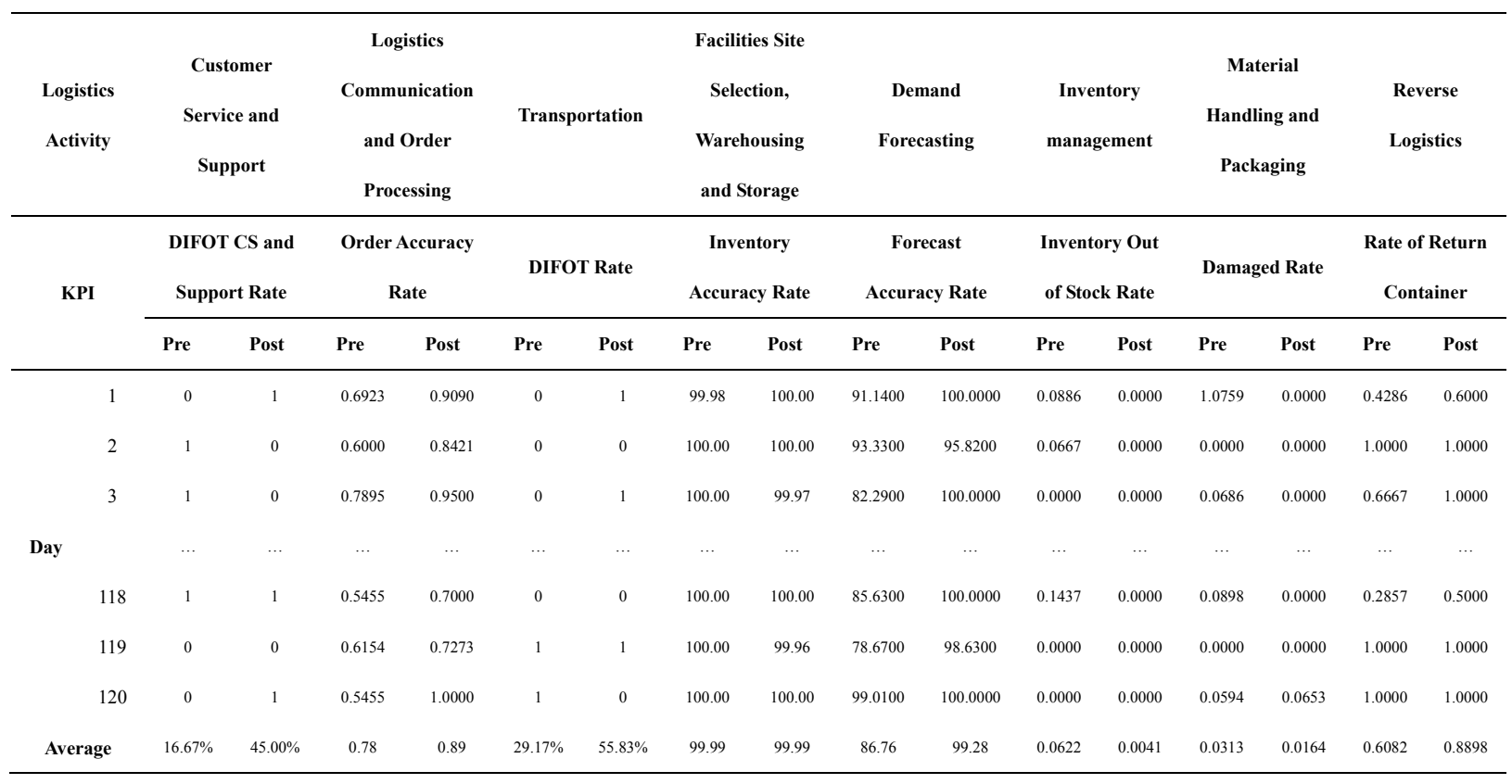

The table 7 shows the result of each logistics performance in term of reliability for one grower within 120 days. This performance is different from pre and post implementation. Only inventory out of stock rate and damage rate are reduced by $0.047 \%$ and $0.016 \%$. As seven of ratios, that are DIFOT CS and support rate, supplier in full and on-time rate, order accuracy rate, DIFOT rate, inventory accuracy rate, forecast accuracy rate, and rate and return container, are increasing from $0.0032 \%$ to $24.17 \%$.

Table 8. Result of t-test of logistics performance

\begin{tabular}{clccc}
\hline \multirow{2}{*}{ Item } & \multirow{2}{*}{ Logistics Activity } & \multicolumn{3}{c}{ Logistics Performance Indicator } \\
& & Cost & Time & Reliability \\
\hline 1 & Customer service and support & PASS & PASS & PASS \\
2 & Sourcing & & & \\
3 & Logistics Communication and Order Processing & & & PASS \\
4 & Transportation & PASS & & PASS \\
5 & Facilities Site Selection, Warehousing and Storage & & & \\
6 & Demand Forecasting and Planning & PASS & PASS & PASS \\
7 & Inventory Management & PASS & PASS & PASS \\
8 & Material Handling and Packaging & PASS & & PASS \\
9 & Reverse Logistics & PASS & PASS & PASS \\
\hline
\end{tabular}

Table 8 shows the result of t-test of all pre and post performances to nine logistics activities of one grower. Logistics performances are cost, time and reliability. The result of t-test is the difference between pre and post, the table indicates "PASS". Cost performance includes customer service and support, transportation, demand forecasting and planning, inventory management, material handling and packaging, and reverse logistics. Time 
performance insists on customer service and support, demand forecasting and planning, inventory management and reverse logistics. Finally, the reliability indicator combines customer service and support, logistics-communication and order processing, transportation, demand forecasting and planning, inventory management, material handling and packaging and reverse logistics.

Table 9. Result of t-test of cost performance

\begin{tabular}{|c|c|c|c|c|c|c|c|c|c|c|c|c|}
\hline Item & Logistics Activity & G1 & G2 & G3 & G4 & G5 & G6 & G7 & G8 & G9 & G10 & Average \\
\hline 1 & Customer service and support & PASS & PASS & PASS & PASS & PASS & PASS & PASS & PASS & PASS & PASS & $100 \%$ \\
\hline \multirow[t]{2}{*}{2} & Sourcing & & & & & & & & & & & $0 \%$ \\
\hline & Communication & & & & & & & & & & & \\
\hline 3 & and Order Processing & & & & & & & & & PASS & & $10 \%$ \\
\hline \multirow[t]{2}{*}{4} & Transportation & PASS & PASS & PASS & PASS & PASS & PASS & PASS & PASS & PASS & PASS & $100 \%$ \\
\hline & Facilities Site Selection, & & & & & & & & & & & \\
\hline \multirow[t]{2}{*}{5} & Warehousing and Storage & & & & & & & & & PASS & & $10 \%$ \\
\hline & Demand Forecasting and & & & & & & & & & & & \\
\hline 6 & Planning & PASS & PASS & PASS & PASS & PASS & PASS & PASS & PASS & PASS & PASS & $100 \%$ \\
\hline \multirow[t]{2}{*}{7} & Inventory Management & PASS & PASS & PASS & PASS & PASS & PASS & PASS & PASS & PASS & PASS & $100 \%$ \\
\hline & Material Handling and & & & & & & & & & & & \\
\hline 8 & Packaging & PASS & & & & & & & PASS & & & $20 \%$ \\
\hline 9 & Reverse Logistics & PASS & PASS & PASS & PASS & & PASS & PASS & PASS & PASS & PASS & $90 \%$ \\
\hline
\end{tabular}

The researcher repeats the t-test to all ten growers on cost performance. The result, as illustrated in table 9 . Logistics activities which the average is $50 \%$ and above will be selected for cost performances. They are customer service and support, transportation management, demand forecasting and planning, inventory management, and reverse logistics.

Table 10. Result of t-test of time performance

\begin{tabular}{|c|c|c|c|c|c|c|c|c|c|c|c|c|}
\hline Item & Logistics Activity & G1 & G2 & G3 & G4 & G5 & G6 & G7 & G8 & G9 & G10 & Average \\
\hline 1 & Customer service and support & PASS & PASS & PASS & PASS & & PASS & PASS & PASS & PASS & PASS & $90 \%$ \\
\hline 2 & Sourcing & & & & & & & & & & & $0 \%$ \\
\hline \multirow{2}{*}{3} & Logistics Communication and & & & & & & & & & & & \\
\hline & Order Processing & & PASS & & & & & PASS & & & PASS & $30 \%$ \\
\hline 4 & Transportation & & PASS & PASS & PASS & PASS & PASS & PASS & PASS & PASS & PASS & $90 \%$ \\
\hline \multirow{2}{*}{5} & Facilities Site Selection, & & & & & & & & & & & \\
\hline & Warehousing and Storage & & PASS & & & & & PASS & & & & $20 \%$ \\
\hline \multirow{2}{*}{6} & Demand Forecasting and & & & & & & & & & & & \\
\hline & Planning & PASS & PASS & PASS & PASS & PASS & PASS & PASS & PASS & PASS & PASS & $100 \%$ \\
\hline 7 & Inventory Management & PASS & PASS & PASS & PASS & PASS & PASS & PASS & PASS & PASS & PASS & $100 \%$ \\
\hline \multirow{2}{*}{8} & Material Handling and & & & & & & & & & & & \\
\hline & Packaging & & PASS & & PASS & & & & PASS & & & $30 \%$ \\
\hline 9 & Reverse Logistics & PASS & PASS & PASS & PASS & PASS & PASS & PASS & PASS & PASS & PASS & $100 \%$ \\
\hline
\end{tabular}

The researcher repeats the t-test to all ten growers on time performance. The result, as illustrated in table 10 Logistics activities which the average is $50 \%$ and above will be selected for time performances. They are 
customer service and support, transportation management, demand forecasting and planning, inventory management, and reverse logistics.

Table 11. Result of t-test of reliability performance

\begin{tabular}{|c|c|c|c|c|c|c|c|c|c|c|c|c|}
\hline Item & Logistics Activity & G1 & G2 & G3 & G4 & G5 & G6 & G7 & G8 & G9 & G10 & Average \\
\hline 1 & Customer service and support & PASS & PASS & PASS & PASS & PASS & PASS & & PASS & PASS & PASS & $90 \%$ \\
\hline 2 & Sourcing & & & & & & & & & & & $0 \%$ \\
\hline \multirow{2}{*}{3} & Logistics Communication and & & & & & & & & & & & \\
\hline & Order Processing & PASS & PASS & PASS & PASS & PASS & PASS & PASS & PASS & PASS & PASS & $100 \%$ \\
\hline 4 & Transportation & PASS & PASS & PASS & PASS & PASS & PASS & PASS & PASS & PASS & PASS & $100 \%$ \\
\hline \multirow[t]{2}{*}{5} & Facilities Site Selection, & & & & & & & & & & & \\
\hline & Warehousing and Storage & PASS & PASS & PASS & PASS & PASS & PASS & PASS & PASS & PASS & PASS & $60 \%$ \\
\hline \multirow{2}{*}{6} & Demand Forecasting and & & & & & & & & & & & \\
\hline & Planning & PASS & PASS & PASS & PASS & PASS & PASS & & & & PASS & $100 \%$ \\
\hline 7 & Inventory Management & PASS & PASS & PASS & PASS & PASS & PASS & PASS & PASS & PASS & PASS & $100 \%$ \\
\hline \multirow{2}{*}{8} & Material Handling and & & & & & & & & & & & \\
\hline & Packaging & PASS & PASS & PASS & PASS & PASS & PASS & PASS & PASS & PASS & PASS & $100 \%$ \\
\hline 9 & Reverse Logistics & PASS & PASS & PASS & PASS & PASS & PASS & PASS & PASS & PASS & PASS & $100 \%$ \\
\hline
\end{tabular}

The researcher repeats the t-test to all ten growers on reliability performance. The result, as illustrated in table 11 . Logistics activities which the average is 50\% and above will be selected for reliability performances. They are customer service and support, logistics, communication and order, transportation management, facility site selection and storage, demand forecasting and planning, inventory management, material handling and packaging and reverse logistics.

Table 12. The summary of logistics performance indicator for orchid flower collaboration

\begin{tabular}{|c|c|c|c|c|}
\hline \multirow{2}{*}{ Item } & \multirow{2}{*}{ Logistics Activity } & \multicolumn{3}{|c|}{ Logistics Performance Indicator } \\
\hline & & Cost & Time & Reliability \\
\hline 1 & Customer service and support & $\begin{array}{c}\text { Ratio of Customer } \\
\text { Service Cost per Sale }\end{array}$ & $\begin{array}{c}\text { Average Order Cycle } \\
\text { Time }\end{array}$ & $\begin{array}{c}\text { Delivery in Full and } \\
\text { On Time Rate }\end{array}$ \\
\hline 2 & Sourcing & N/A & $\mathrm{N} / \mathrm{A}$ & $\mathrm{N} / \mathrm{A}$ \\
\hline 3 & $\begin{array}{l}\text { Logistics Communication and } \\
\text { Order Processing }\end{array}$ & $\mathrm{N} / \mathrm{A}$ & N/A & $\begin{array}{l}\text { Order Accuracy } \\
\text { Rate }\end{array}$ \\
\hline 4 & Transportation & $\begin{array}{l}\text { Ratio of Transportation } \\
\text { Cost per Sale }\end{array}$ & $\begin{array}{l}\text { Average Delivery } \\
\text { Cycle Time }\end{array}$ & $\begin{array}{l}\text { Delivery in Full and } \\
\text { On Time Rate }\end{array}$ \\
\hline 5 & $\begin{array}{l}\text { Facilities Site Selection, } \\
\text { Warehousing and Storage }\end{array}$ & N/A & $\mathrm{N} / \mathrm{A}$ & Inventory Accuracy \\
\hline 6 & $\begin{array}{l}\text { Demand Forecasting and } \\
\text { Planning }\end{array}$ & $\begin{array}{l}\text { Ratio of Forecasting } \\
\text { Cost per Sale }\end{array}$ & $\begin{array}{l}\text { Average Forecast } \\
\text { period }\end{array}$ & $\begin{array}{c}\text { Forecast Accuracy } \\
\text { Rate }\end{array}$ \\
\hline 7 & Inventory Management & $\begin{array}{l}\text { Ratio of Inventory } \\
\text { Holding Cost per Sale }\end{array}$ & $\begin{array}{l}\text { Average Inventory } \\
\text { Day }\end{array}$ & $\begin{array}{l}\text { Inventory Out of } \\
\text { Stock Rate }\end{array}$ \\
\hline 8 & $\begin{array}{l}\text { Material Handling and } \\
\text { Packaging }\end{array}$ & N/A & $\mathrm{N} / \mathrm{A}$ & Damage Rate \\
\hline 9 & Reverse Logistics & $\begin{array}{c}\text { Ratio of Return } \\
\text { Container Value per Sale }\end{array}$ & $\begin{array}{l}\text { Average Cycle Time } \\
\text { for Container Return }\end{array}$ & $\begin{array}{l}\text { Rate of Return } \\
\text { Container }\end{array}$ \\
\hline
\end{tabular}


Finally, a collaborative performance metric of orchid flower supply chain is illustrated as in table 12 . The "N/A" is not applicable to this measurement because there is no difference between pre and post collaboration.

\section{Conclusion}

Logistics Collaboration in orchid supply chain is a unique model that bases on supply chain collaboration and logistics activities. The methodology is related to model formation and model adjustment with orchid stakeholders in Bangkok, Thailand from 2012 to 2014. They are ten growers and an exporter whom participate in logistics activities collaboration. The t-test technique is used for evaluating the logistics performance indicator applicable. The results show five logistics indicators can be used for time and cost. They are customer service and support, transportation, demand forecasting and planning, inventory management and reverse logistics. On the other hand, reliability-performance indicator combines eight logistics performance indicator of nine indicators. The next step of this research will focus all stakeholders in orchid flower supply chain. It will take one years to collect all data and implement with them.

\section{References}

Akintoye, A. (2000). Analysis of factors influencing project cost estimating practice. Construction Management and Economics, 18(1), 77-89.

Arganistapechart, K. (2005). Study the potential of Thai orchid flower in Japan market. Bangkok: Ministry of Agriculture.

Aslan, S., \& Ahmet, D. (2013). A research on the problems encountered in the collaboration between university and industry (pp. 966-975). Procedia: Social and behavioral science.

Bangkok Business Directory. (2012). Directory Bangkok. Retrieved August 2011, from http://www.directorybangkok.com/

Barratt, M., (2004). Understanding the meaning of collaboration in the supply chain. Supply Chain Management: An International Journal, 9(1), 30-42. http://dx.doi.org/10.1108/13598540410517566

Benavides, L., Eskinazis, V. D., \& Swan, D. (2012). Six steps to successful supply chain collaboration. Washington: CSCMP's Supply Chain Quarterly.

Betts, T., \& Tadisina, S. (2009). Supply chain agility, collaboration and performance: How do they realte? Proceeding of annual conference of the production and operation management science.

Bloss, R., (2014). Automated carton making, order filling and goods movement lifts material handling to new heights of efficiency. Assembly automation, 34(1), 23-26. http://dx.doi.org/10.1108/AA-03-2013-016

Caridi, M., Cigolini, R., \& Marco, D. (2005). Improving supply chain collaboration by linking intelligent agents to CPFR. International journal of production research, 4191-4218. http://dx.doi.org/10.1080/00207540500142134

Chen, D.-J., Chen, H.-C., \& Lai, S.-H. (2010). The effect of adopting collaboration transportation management by Taiwanese computer manufacturer-model building and empirical studies. International journal of information and management sciences, 484-499.

Cooper, D. R., \& Schindler, P. S., (2014). Business research methods. Irwin: McGraw-Hill.

Danese, P. (2007). Designing CPFR collaboration: Insights from seven case studies. International journal of operation and production management, 181-204. http://dx.doi.org/ 10.1108/01443570710720612

Dhamniyam, U. (2013). Forecasting the trend of exporting value from Thailand to Japan. Chiang Mai: S.N.

Du, X. F., Leung, S. C., Zhang, J. L., \& Lai, K. K. (2009). Procurement of agricultural products using CPFR approach. An international journal, 253-258. http://dx.doi.org/10.1108/13598540910970081

Eksoz, C., Mansouri, A., \& Bourlakis, M. (2014). Collaborative forecasting in the food supply chain: A conceptual framework. International journal of production economics, 120-135. http://dx.doi.org/10.1016/j.ijpe.2014.07.031

Everythings, O. (2013). Types of Orchids. Retrieved October 24, 2013 from http://everything-orchids.com/types-of-orchids

Eyaa, S., Ntayi, J. M., \& Namagembe, S., (2010). Collaborative relationships and SME supply chain performance. World Journal of Enterprenuership, Management and Sustainable Development, 233-245. http://dx.doi.org/10.1108/20425961201000018 
Fathen, J., Muhammad, M., \& Egide, K. (2012). Initial Perceptions and Adoption of E-Business in a Timeline (pp. 7-28). Annual Conference of the Administrative Sciences Association of Canada.

Fawcett, S. E., Fawcett, A. M., Watson, B. J., \& Magnan, G. M. (2012). Peeking Inside The Black Box: Toward and understanding of supply chain collaboration dynamics. Journal of supply chain management, 48(1), 44-72. http://dx.doi.org/10.1111/j.1745-493X.2011.03241.x

Frazelle, E. (2002). Supply Chain Strategy: The logistics of supply chain management. New York: McGraw-Hill.

Fu, Y., \& Piplani, R. (2004). Supply-side collaboration and its value in supply chains. European journal of operational research, 281-288. http://dx.doi.org/10.1016/S0377-2217(02)00670-7

Humphries , A. S., \& Wilding, R. (2004). Long term collaborative business relationships: The impact of trust and C3 behaviour. Journal of marketing management, 20(9-10), 1107-1122.

Hwang, H. J., \& Seruga, J. (2011). An intelligent supply chain management system to enhance collaboration in textile industry. International journal of $u$ - and e-service, science and technology, 4(4), 47-61.

Kaipia, R., Dukovska-Popovska, I., \& Loikkanen, L. (2013). Creating sustainable fresh food supply chains through waste reduction. International journal of physical distribution \& logistics management, 43(3), 262-276. http://dx.doi.org/10.1108/IJPDLM-11-2011-0200

Karuranga, E., Frayet, J., \& D’Amour, S. (2002). Sectorial and regional characteristics of Canadian knowledge-intensive business service. Journal of forest product business research, 1-18.

Kimiloglu, H., Ozturan, M. \& Erdem, A. S., (2012). Collaborative Research: Opinions and information technology utilization potential. Management research review, 35(12), 1134-1152. http://dx.doi.org/10.1108/01409171211281264

Kroon, L., \& Vrijens, G. (1995). Returnable containers: An example of reverse logistics. International journal of physical distribution \& logistics management, 25(2), 56-68. http://dx.doi.org/10.1108/09600039510083934

Kohli, A., \& Jensen, J. (2010). Assessing effective of supply chain collaboration. Supply chain forum: An international journal, 2-16.

Lambert, D. M., Emmelhainz, M. A., \& Gardner, J. T. (1996). Developing and implementing supply chain partnership. The international journal of logistics management, $7(2)$. http://dx.doi.org/10.1108/09574099610805485

Lin, C., (2008). A cooperative strategy for a vehicle routing problem with pickup and delivery time windows. Computer \& industrial engineering. http://dx.doi.org/10.1016/j.cie.2008.03.001

MacKenzie, S. K. (2000). UK construction skills shortage response strategies and an analysis of industry perceptions . Construction Management and Economics, 853-862.

Mahidol, C. (2013). Project: Research and production the orchid industry. Retrieved November 20, 2013, from http://www.royal.mju.ac.th/about_project.php?id_sub=7\&id_pro=0

Mathuramaytha, C. (2011). Supply chain collaboration-What's an outcome?: A theoretical model. International conference on financial management and economics. Singapore.

Mugarura, J. T. (2010). Buyer-supplier collaboration, adaptation, trust, commitment and relationship continuity of selected private manufacturing firms in Kampala. Makerere University.

Nasiri, R. G., Davoudpour, H., \& Karimi, B., (2010). The impact of integrated analysis of supply chain management: a coordinated approach for inventory control policy. Supply chain management: An international journal, 15(4), 277-289. http://dx.doi.org/10.1108/13598541011054652

Nuchanapai, S., (2012). An analysis of market potential for Thai major orchids export. Bangkok: Department of agricultural and resource, Kasets University.

Palmer, A., Saenz, M. J., Woensel, T. V., \& Ballot, E. (2012). Characteristics of collaborative business models. Edinburgh: S. N.

Peel, M., \& Rowley, J., (2010). Information sharing practice in multi-agency working. New information perspectives, 11-28. http://dx.doi.org/10.1108/00012531011015172

Piplani, R., \& Fu, Y. (2005). A coordination framework for supply chain inventory alignment. Journal of manufacturing technology management, 598-614. http://dx.doi.org/10.1108/17410380510609465

Poler, R., Hernandez, E., Mula, J., \& Lario, F. C. (2008). Collaborative forecasting in networked manufacturing 
enterprises. Journal of manufacturing technology management, 19(4), 514-528. http://dx.doi.org/10.1108/17410380810869941

Power, D. (2008). Capability and practice in procurement collaboration: A vendor's perspective of benefits. Operation and supply chain management, 72-84. http://dx.doi.org/10.1108/09574090510634548

Ramanathan, U., \& Muyldermans, L. (2010). Identifying demand forecasting factors for promotional planning and forecasting: A case of soft drink company in the UK. International journal of production economics, 538-545. http://dx.doi.org/10.1016/j.ijpe.2010.07.007

Ramanathan, U., Gunasekaran, A., \& Subramanian, N., (2011). Supply chain collaboration performance metrics: A conceptual framework. Benchmarking: An international journal, 18(6), 856-872. http://dx.doi.org/10.1108/14635771111180734

Rossi, S. (2012). Challenges for Co-Modality in a Collaborative Environment. S.1.: S. N.

Salema, I. G., Póvoa, B., \& Novais. (2007). An optimization model for the design for a capaitated multi-product reverse logistics network with uncertainty. European journal of operation reserach, 1063-1077.

Sandberg, E. (2007). Logistics collaboration in supply chains: Practice vs. theory. The international journal of logistics management, 274-293. http://dx.doi.org/10.1108/09574090710816977

Sawik, T. (2013). Joint supplier selection and scheduling of customer orders under disruption risks: Single vs. dual sourcing. Omega. http://dx.doi.org/10.1016/j.omega.2013.06.007

Sheffi, Y. (2002). The value of CPFR. Fourth international congress on logistics research. Portugal: IMLR

Simatupang, T. M., \& Sridharan, R. (2005). An integrative framework for supply chain collaboration. The international journal of logistics management, $16(2), \quad 257-274$. http://dx.doi.org/10.1108/09574090510634548

Stefansson, G. (2006). Collaborative logistics management and the role of third-party service providers. International journal of physical distribution \& logistics management, 6(2), $76-92$. http://dx.doi.org/10.1108/09600030610656413

Taijidan, B. S., Muslich, M., \& Wahib, M. (2013). The casuality relationship between managment in supply chain collaboration with the prosperity corn farmers in WestNusa Tenggara, Indonesia. European Journal of Business and Management.

Taylor, J. W. (2007). Forecasting daily supermarket sales using exponentially weighted quantile regression. European Journal of operational research, 154-167.

\section{Copyrights}

Copyright for this article is retained by the author(s), with first publication rights granted to the journal.

This is an open-access article distributed under the terms and conditions of the Creative Commons Attribution license (http://creativecommons.org/licenses/by/3.0/). 